\title{
A new genus and species of a galliform bird from the Oligocene of Poland
}

\author{
Teresa Tomek, Zbigniew M. Bochenski, Krzysztof Wertz, and Ewa Swidnicka
}

\begin{abstract}
We describe an articulated partial skeleton representing a new genus and species, Sobniogallus albinojamrozi gen. et sp. nov., of an early Oligocene galliform bird from Poland. In overall osteology, mainly of the sternum, furcula, and humerus, the specimen resembles extant Galliformes but differs from that group in several characters including the "anseriform" carpometacarpus, which is typical for stem group galliform birds. The present study supports the notion that Galliformes and Anseriformes are sister taxa that together form the clade Galloanseres. The new species increases the known diversity of avian remains recovered from the Outer Carpathians and Central Paleogene Basin of Europe.
\end{abstract}

Teresa Tomek. Institute of Systematics and Evolution of Animals, Polish Academy of Sciences, Slawkowska 17, 31-016 Kraków, Poland. tomek@isez.pan.krakow.pl

Zbigniew M. Bochenski. Institute of Systematics and Evolution of Animals, Polish Academy of Sciences, Slawkowska 17, 31-016 Kraków, Poland. bochenski@isez.pan.krakow.pl corresponding author Krzysztof Wertz. Institute of Systematics and Evolution of Animals, Polish Academy of Sciences, Slawkowska 17, 31-016 Kraków, Poland. wertz@isez.pan.krakow.pl

Ewa Swidnicka. Department of Palaeozoology, Chair of Evolutionary Biology and Ecology, University of Wrocław, Sienkiewicza 21, 50-335 Wrocław, Poland. gama@biol.uni.wroc.pl

Keywords: fossil birds; new genus; new species; feathers; Menilite shales; Carpathian flysch; Palaeogene

\section{INTRODUCTION}

With almost 300 species distinguished, the order Galliformes has a worldwide distribution (del Hoyo et al., 1994). Some of the species have a very abundant fossil record, especially from the late Pleistocene and Holocene sediments. The oldest crown group Galliformes are Phasianidae and Megapodiidae, whose remains are dated to the late Oligocene (Mayr, 2009). The Palaeogene fossil record of galliform birds is also rich and shows much diversity (Mayr, 2009). Three extinct families (Gallinuloididae, Paraortygidae, and Quercymegapodiidae) that together include a dozen species have been described from the Palaeogene so far. The Gallinuloididae (Gallinuloides and Paraortygoides) are known from the early Eocene of North America and the early and middle Eocene of

http://zoobank.org/BFA47413-EEFD-4D0E-BD96-04249019A60D

PE Article Number: 17.3.38A

Copyright: Palaeontological Association October 2014

Submission: 1 April 2014. Acceptance: 23 September 2014

Tomek, Teresa, Bochenski, Zbigniew M., Wertz, Krzysztof, and Swidnicka, Ewa. 2014. A new genus and species of a galliform bird from the Oligocene of Poland. Palaeontologia Electronica Vol. 17, Issue 3;38A; 15p;

palaeo-electronica.org/content/2014/933-galliform-bird-from-oligocene 
Europe (Mayr, 2000, 2009; Mayr and Weidig, 2004; Mourer-Chauviré, 1992; Mourer-Chauviré et al., 2013). The Paraortygidae are known from the late Eocene and early Oligocene of France, Germany, and Belgium (Paraortyx) and late Oligocene of France, Germany, and Belgium (Pirortyx) (Fischer, 1990, 2003; Mayr, 2009; Mayr and Smith, 2013; Mourer-Chauviré, 1992). According to Mayr (2009), Taoperdix pessieti from the late Oligocene of France, Procrax brevipes from the late Eocene of the USA, and Archaealectrornis sibleyi from the early Oligocene of the USA may be further representatives of the Paraortygidae. The Quercymegapodiidae are known from the middle and late Eocene of France (Quercymegapodius), the late Oligocene or early Miocene of Brazil (Ameripodius silvasantosi and Taubacrex granivora), and the early Miocene of France (Ameripodius alexis) (Alvarenga, 1988, 1995; Mayr, 2009; MourerChauviré, 1992; 2000). According to Mayr (2005, 2009), Ludiortyx hoffmanni from the late Eocene of the Paris Gypsum probably also belongs to Quercymegapodiidae. Moreover, a number of galliform species comparable in size to a quail have been described from Europe, Africa, and North America, although their systematic affinities are still uncertain (e.g., Mayr, 2009; Mourer-Chauviré et al., 2011, 2013).

Most of the galliform fossils are known from isolated bones. Sometimes they include many skeletal elements, as is the case in the Phosphorites du Quercy, France, but other localities often provide less abundant material. Associated skeletons from the Palaeogene, like the one described here, are very rare. The specimen described in this paper is the first galliform from the Oligocene of Poland and the easternmost from the Palaeogene of Europe. Although it is incomplete, it provides many new details of the earliest galliform birds.

\section{MATERIAL AND METHODS}

Osteological terminology follows Baumel and Witmer (1993). Dimensions are given in millimeters and refer to the greatest length along the longitudinal axis of the bone. The fossil was compared with comparative specimens from the osteological collection of the Institute of Systematics and Evolution of Animals, Polish Academy of Sciences, Kraków, Poland, and with published data on the osteology of extant and fossil Galliformes. The fossiliferous horizon of the type locality, Sobniów (nowadays within the town of Jasło), has been dated on the basis of about 260 fish specimens found at the same layers of Jasło limestone (Jerzmańska, 1960; Kotlarczyk et al., 2006).

\section{SYSTEMATIC PALEONTOLOGY}

\author{
Class AVES Linnaeus, 1758 \\ Order GALLIFORMES Temminck, 1820 \\ Family incertae sedis \\ Genus Sobniogallus gen. nov. \\ zoobank.org/05A846C6-6E1D-4665-8694-7DCCAAA4B07C
}

Type species. Sobniogallus albinojamrozi sp. nov. Etymology. The genus name is a composite: the first part, Sobnio, is from the type locality Sobniów, added to the Latin gallus, meaning a gallinaceous bird.

Taxonomic remarks. A small galliform bird which is distinguished from members of all other avian orders by the combination of the following characters: (1) the sternum bears the spina interna that is fused with the spina externa to form the spina communis that protrudes cranially, (2) bears the foramen rostri at its base, and (3) two well pronounced cristae lateralis carinae that border the deep and wide sulcus carinae; (4) the furcula bears a very large and blade-like apophysis furculae; (5) the humerus shows second fossa pneumotricipitalis, (6) a transverse ridge at the beginning of the incisura capitis, and (7) a proximodistally short crista deltopectoralis whose ventral surface is almost perpendicular to the cranial surface of the humerus shaft. For distribution of characters (1), (2), and (6) among chosen Anseriformes and Galliformes see Ksepka (2009). According to Mayr (2000), at least characters (4) and (5) are derived within neognathous birds.

Differential diagnosis. A small galliform bird, somewhat smaller than the Grey Partridge Perdix perdix.

Sobniogallus gen. nov., differs from:

* all genera of the crown group Galliformes (Megapodiidae, Cracidae, Numididae, Odontophoridae, and Phasianidae) in: furcula being extremely robust; humerus with pronounced tuberculum ventrale, tuberculum dorsale separated from the caput humeri by a furrow, crista bicipitalis merging with the shaft at a steeper angle, sulcus ligamentosus transversus much deeper and extending to the tuberculum ventrale, and processus flexorius reaching about as far distally as the condylus ventralis (it is always shorter in extant Galliformes); carpometacarpus narrow with straight os metacarpale minus (bowed in extant Galliformes), processus intermetacarpalis rudimentary (in Odontophoridae 
and Phasianidae it is well-developed, in Numididae it is missing, and in Cracidae and Megapodiidae it is also rudimentary), and the articular surface of the os metacarpale minus extending less distally than the articular surface of the os metacarpale majus (much farther distally in all extant Galliformes);

* Gallinuloides Eastman, 1900 in: scapus claviculae (furcula) becoming wider towards extremitas omalis (of equal width in Gallinuloides); presence of a second fossa pneumotricipitalis (humerus) which does not extend into the caput humeri; presence of a transverse ridge at the beginning of the incisura capitis (humerus); carpometacarpus with the articular surface of the os metacarpale minus extending slightly less distally than the articular surface of the os metacarpale majus;

* Paraortygoides Mayr, 2000 in: presence of spina interna (sternum) that fuses with spina externa to form a spina communis; humerus with a second fossa pneumotricipitalis which does not extend into the caput humeri and a transverse ridge at the beginning of the incisura capitis; ulna longer than humerus; carpometacarpus with rudimentary processus intermetacarpalis (absent in Paraortygoides), and the articular surface of the os metacarpale minus extending slightly less distally than the articular surface of the os metacarpale majus;

* Paraortyx Gaillard, 1908 in: humerus with shallow second fossa pneumotricipitalis which does not extend into the caput humeri, transverse ridge at the beginning of the incisura capitis, and tuberculum dorsale separated from the caput humeri by a furrow; carpometacarpus with processus extensorius more protruding proximo-cranially, the articular surface of the os metacarpale minus extending slightly less distally than the articular surface of the os metacarpale majus;

* Pirortyx Brodkorb, 1964 in: humerus with a transverse ridge at the beginning of the incisura capitis, and tuberculum dorsale separated from the caput humeri by a furrow;

* Taoperdix Milne-Edwards, 1871 in: furcula with wider scapus claviculae ( $3.0 \mathrm{~mm}$ vs. 1.3 $\mathrm{mm}$ in Taoperdix pessieti); humerus with pronounced tuberculum dorsale that is separated from the caput humeri by a furrow; ulna longer than humerus (in Taoperdix pessieti slightly shorter);

* Procrax Tordoff and Macdonald, 1957 in: humerus more slender, with more pronounced tuberculum dorsale, and more abrupt connection of the crista bicipitalis with the shaft; carpometacarpus with less bowed os metacarpale minus;

* Archaealectrornis Crowe and Short, 1992 in: humerus with a transverse ridge at the beginning of the incisura capitis, pronounced tuberculum ventrale, tuberculum dorsale separated from the caput humeri by a furrow, and more abrupt connection of the crista bicipitalis with the shaft;

* Quercymegapodius Mourer-Chauviré, 1992 in: humerus with tuberculum dorsale separated from the caput humeri by a furrow; carpometacarpus with processus extensorius more protruding proximo-cranially, and the articular surface of the os metacarpale minus extending slightly less distally than the articular surface of the os metacarpale majus;

* Ameripodius Alvarenga, 1995 in: coracoid with more elongated angulus medialis; humerus with tuberculum dorsale separated from the caput humeri by a furrow; carpometacarpus with rudimentary processus intermetacarpalis (absent in Ameripodius), and the articular surface of the os metacarpale minus extending slightly less distally than the articular surface of the os metacarpale majus;

* Taubacrex granivora Alvarenga, 1988 in: coracoid stouter (shaft wider) with more elongated angulus medialis;

* Ludiortyx hoffmanni (Gervais, 1852) in: ulna longer than humerus (in Ludiortyx slightly shorter).

The genera Argillipes Harrison and Walker, 1977 and Percolinus Harrison and Walker, 1977 are known from proximal tarsometatarsi only and the species Chambiortyx cristata Mourer-Chauviré, Tabuce, El Mabrouk, Marivaux, Khayati, VianeyLiaud, Ben Haj Ali, 2013 is known from distal tarsometatarsus and a fragment of distal carpometacarpus only, and therefore they cannot be compared with Sobniogallus gen. nov.

Sobniogallus albinojamrozi gen. et sp. nov. zoobank.org/BCECA3B2-EE57-4CE2-996C-7FDECA10881A

Etymology. The species is named after Albin Jamróz, who collected the specimen.

Holotype. Articulated skeleton without head and legs, preserved on two slabs (Figures 1, 2, 3, 4, 5), deposited in the Institute of Systematics and Evolution of Animals, Polish Academy of Sciences, Kraków, Poland (ISEA AF/SOB1a+b).

Type locality and horizon. Abandoned brickyard at Sobniów, nowadays within the town of Jasło, ca. 

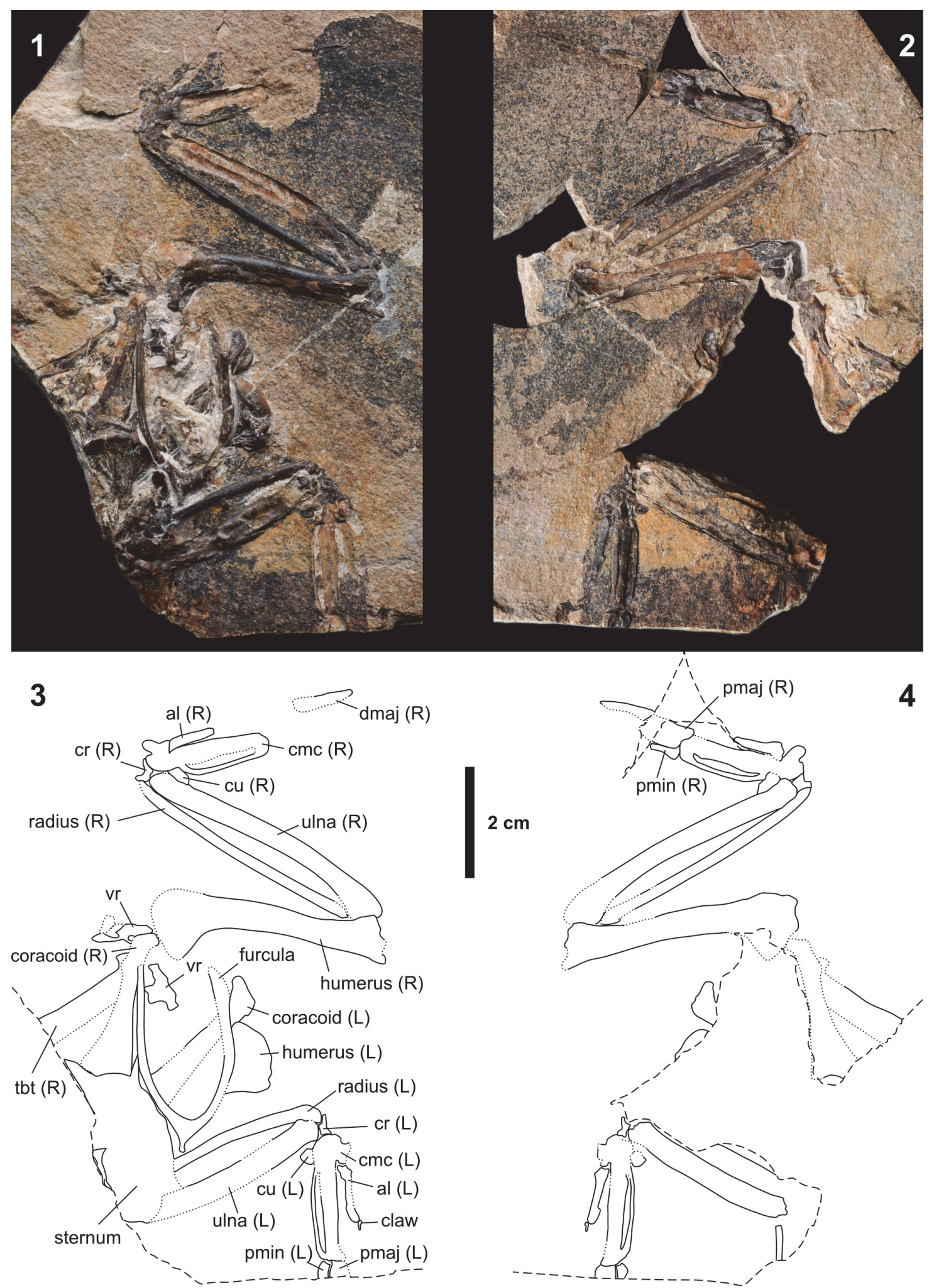

$2 \mathrm{~cm}$

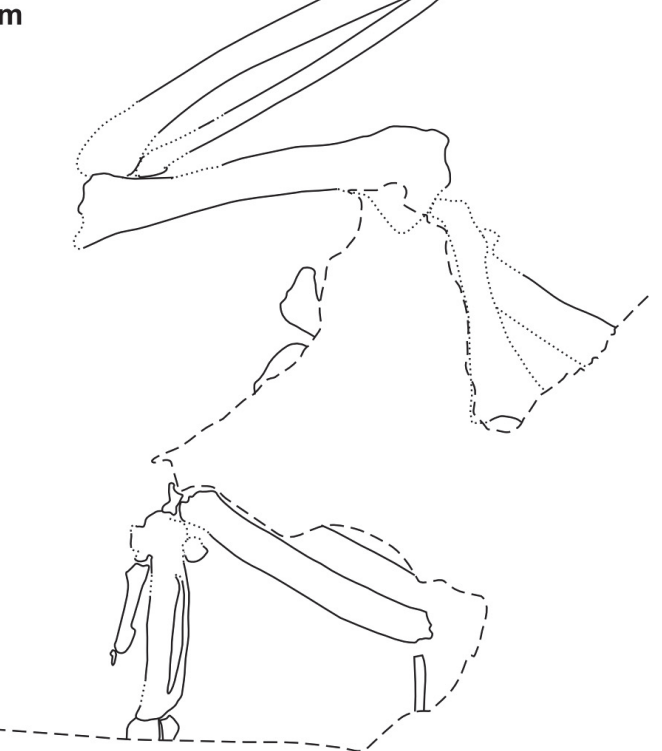

FIGURE 1. Sobniogallus albinojamrozi gen. et sp. nov., holotype, specimen ISEA AF/SOB1a+b from Sobniów, Poland, early Oligocene (top) and interpretative drawings (bottom). 1 and 3, main slab; $\mathbf{2}$ and 4, counterslab. Left (L) and right $(\mathrm{R})$ elements are indicated. Abbreviations: al - phalanx digiti alulae, $\mathrm{cmc}$ - carpometacarpus, $\mathrm{cr}$ - os carpi radiale, $\mathrm{cu}$ - os carpi ulnare, dmaj - phalanx distalis digiti majoris, pmaj - phalanx proximalis digiti majoris, pmin phalanx digiti minoris, tbt - tibiotarsus, vr - vertebrae. 


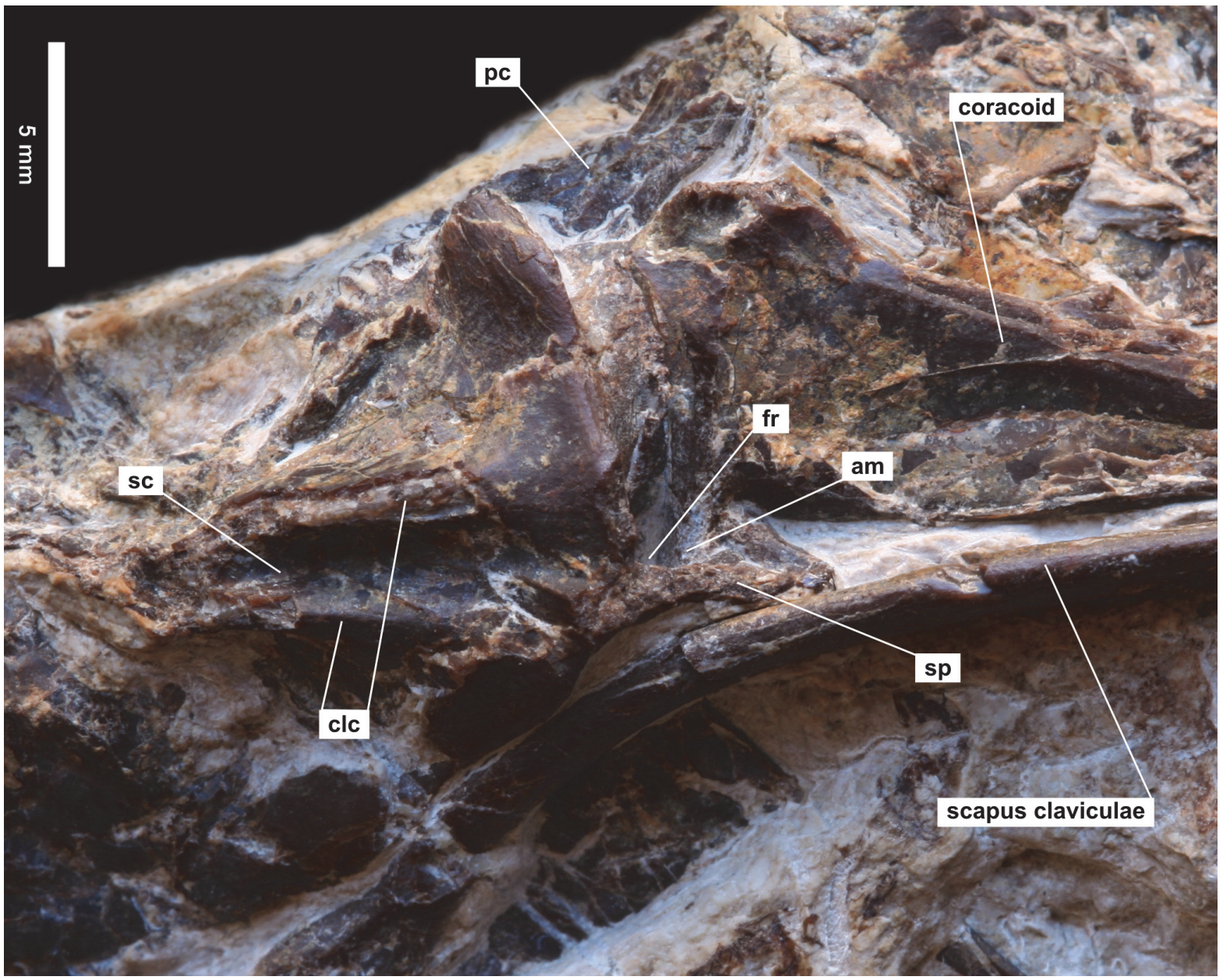

FIGURE 2. Sobniogallus albinojamrozi gen. et sp. nov., holotype, specimen ISEA AF/SOB1a+b from Sobniów, Poland, early Oligocene. Sternum and right coracoid, main slab. Abbreviations: am - angulus medialis, clc - crista lateralis carinae, $\mathrm{fr}$ - foramen rostri, $\mathrm{pc}$ - processus craniolateralis, sc - sulcus carinae, sp - spina communis.

50 km south-west of Rzeszów, Podkarpackie Voivodeship, SE Poland; geographical coordinates of Sobniów $49^{\circ} 43.16^{\prime} \mathrm{N} ; 21^{\circ} 29.31^{\prime} \mathrm{E}$; late Rupelian, early Oligocene, ca. 29-28.5 m.y.a., Jasło limestone of the sequence of Krosno Formation of the Silesian Unit, Outer Carpathians; correlated with the ichthyofaunal IPM4 zone (Kotlarczyk et al., 2006) and the calcareous nannoplankton NP 24 zone sensu Martini (1971) (see also Berggren et al., 1995; Bochenski et al., 2013a). Nowadays the area is divided between new buildings and a recreation center, and the remaining parts of the fossiliferous horizon are buried and/or not available for study. Detailed information on the site and its rich fossil fauna can be found in older papers (Haczewski, 1989; Jerzmańska, 1960; Jerzmańska and Jucha, 1963; Jucha, 1969; Kotlarczyk et al., 2006).

Diagnosis. As for the genus

\section{Description and Comparison}

The specimen is preserved on two slabs; its elements are in articulation (Figure 1). Unlike most other specimens retrieved from the Outer Carpathians, its bones often protrude from the slabs or are buried in the matrix. In fact, some of the skeletal elements are situated below others and all of them are very brittle, which makes further preparation of the specimen rather risky.

Measurements (in $\mathrm{mm}$ ) taken from the slab (s) or counter slab (c) and left or right bone, whichever was better preserved: coracoid, length 27.4 (right, s); humerus, length 43.3 (right, c), proximal width 13.2 (left, s), distal width 8.6 (right, s); ulna, length 47.1 (right, s); radius, length 45.0 (right, s); carpometacarpus, length 23.7 (left, c), proximal width 6.7 (right, s), distal width 3.9 (right, c); phalanx digiti alulae, length 10.6 (left, c); claw on the phalanx digiti alulae, length $\sim 1.8$ (left, c); phalanx proximalis 


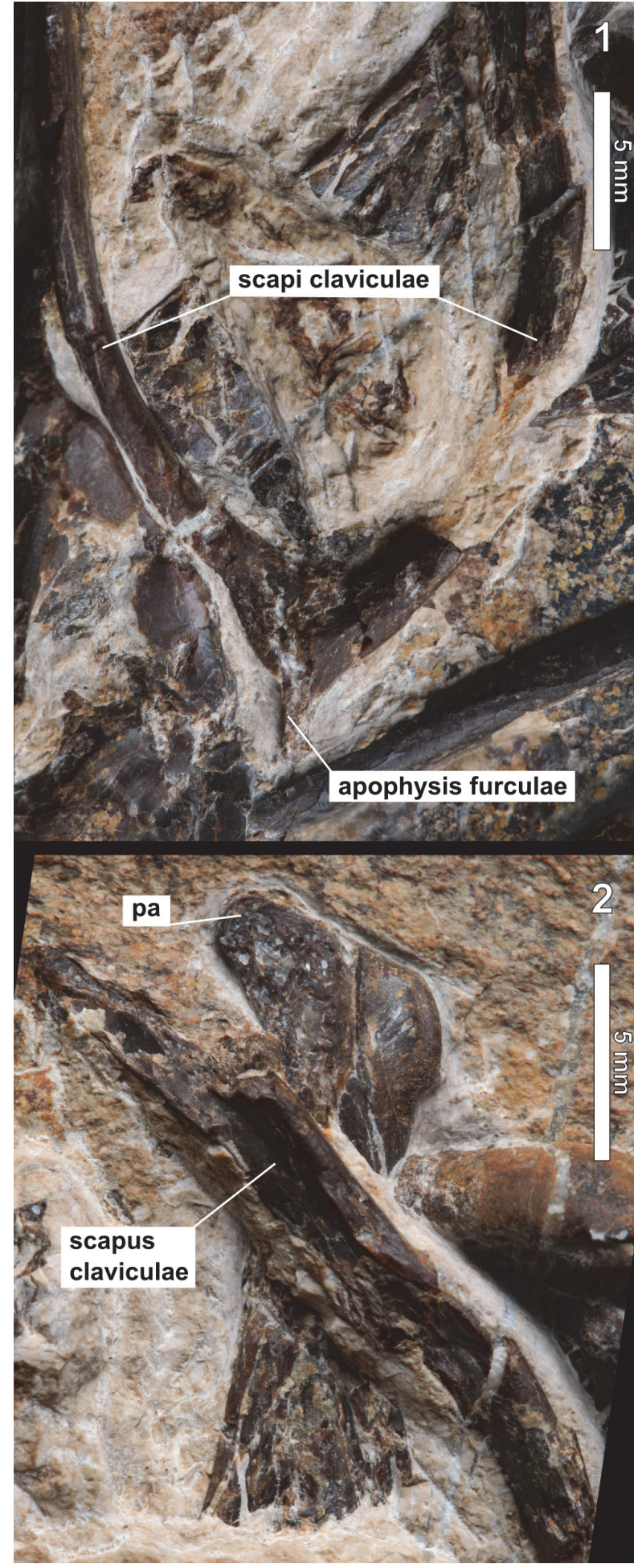

FIGURE 3. Sobniogallus albinojamrozi gen. et sp. nov., holotype, specimen ISEA AF/SOB1a+b from Sobniów, Poland, early Oligocene. 1, Furcula, main slab; 2, left coracoid in ventral view, main slab. Abbreviation: pa processus acrocoracoideus. digiti majoris, length 9.5 (right, c); phalanx distalis digiti majoris, length $>10.4$ (right, c); phalanx digiti minoris, length 5.4 (right, c).

Sobniogallus differs in its absolute size from most stem group Galliformes with preserved corresponding bones (Table 1). Four species (Gallinuloides wyomingensis, Paraortyx brancoi, Pirortyx major, and Ameripodius alexis) are clearly larger and three other (Quercymegapodius depereti, Quercymegapodius brodkorbi, and probably also Chambiortyx cristata) are smaller. Moreover, Ameripodius silvasantosi have relatively longer phalanx proximalis digiti majoris, while the length of its other elements is similar to that in Sobniogallus. Differences in relative lengths of the humerus and ulna in other species are mentioned below in the description of the ulna.

Vertebrae. At least two presacral vertebrae are partly buried in the matrix, but they are too poorly preserved to allow meaningful comparison.

Sternum. The sternum is visible in ventral view with the carina sterni protruding ventrally (Figure 2). Relatively well preserved is the cranial portion of the sternum, while a large part of the crista sterni is broken off and the caudal end of the corpus sterni is missing or hidden in the matrix. As in crown group Galliformes, the spina interna of the rostrum is not only present but fuses with the spina externa to form the spina communis that protrudes cranially and bears the foramen rostri at its base. The spina interna and, consequently, the foramen rostri are absent in the early Oligocene Paraortyx brancoi from Belgium (Mayr and Smith, 2013) and the middle Eocene Paraortygoides messelensis from Germany (Mayr, 2006, figure 3a). The two cristae laterales carinae are well pronounced, and the sulcus carinae that runs between them is deep and wide as in extant Galliformes and the two Palaeogene species with preserved partial sternum mentioned above. Additionally, as in extant Galliformes, the processus craniolateralis is relatively narrow and reaches far cranially.

Furcula. The furcula is visible in cranial view (Figure 3.1). It is U-shaped as in some extant Galliformes and the two Eocene species Paraortygoides messelensis and Gallinuloides wyomingensis. As in Paraortygoides messelensis, Gallinuloides wyomingensis, and Ameripodius silvasantosi, the furcula has very robust scapi claviculae (width of about $3 \mathrm{~mm}$ in mid-length) that are much slender in all representatives of the crown group Galliformes. As in Paraortygoides, Ameripodius, and extant Numida, the scapi claviculae become wider towards extremitas omalis (i.e., oval 


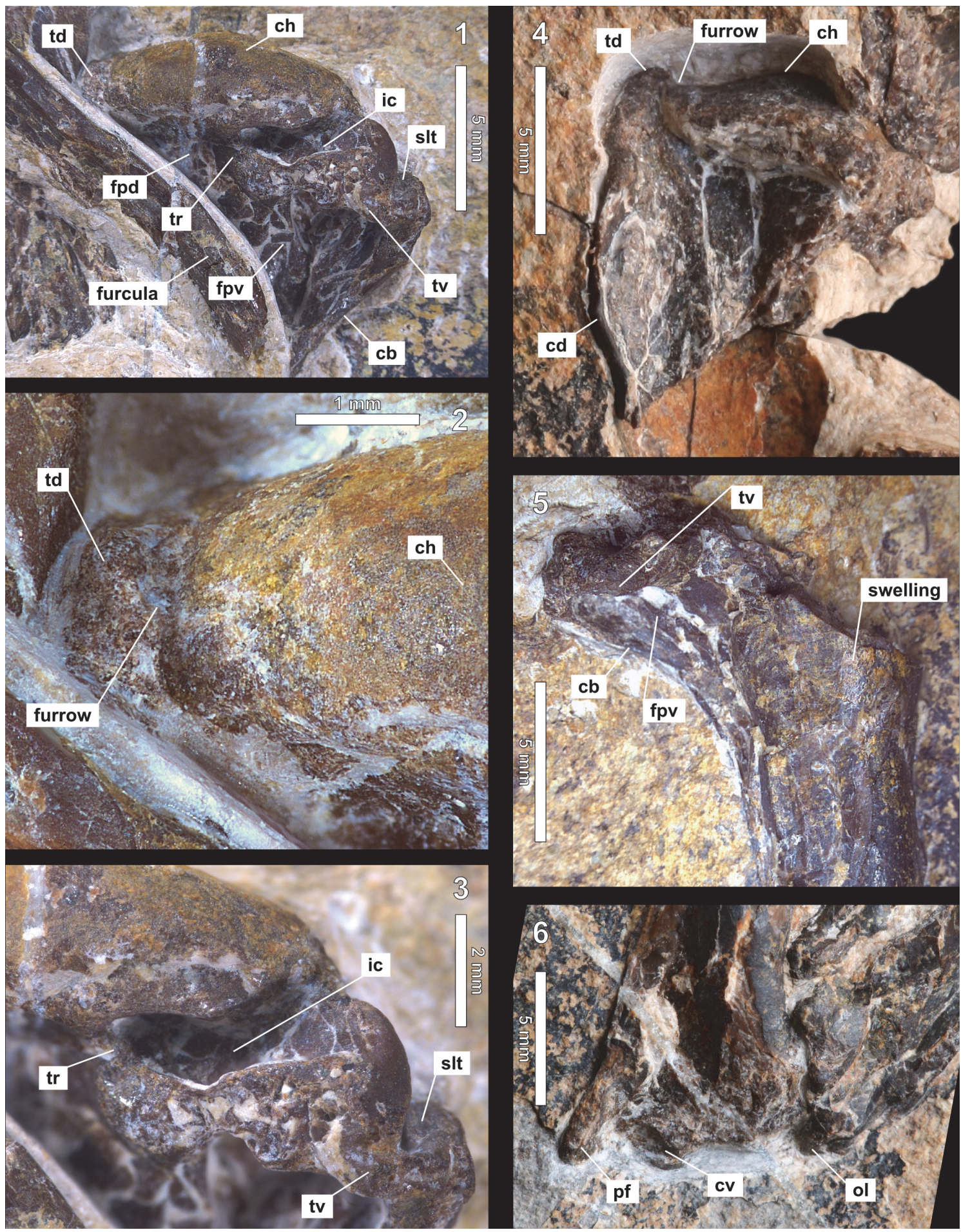

FIGURE 4. Sobniogallus albinojamrozi gen. et sp. nov., holotype, specimen ISEA AF/SOB1a+b from Sobniów, Poland, early Oligocene. 1, proximal left humerus in caudal view, main slab; 2, Enlargement of \#1: tuberculum dorsale and fragment of caput humeri; 3, Enlargement of \#1: incisura capitis closed by a transverse ridge and deep sulcus ligamentosus transversus extending to the tuberculum ventrale; $\mathbf{4}$, proximal right humerus in cranial view, counter slab; 5, proximal right humerus in caudal view, main slab; 6, distal right humerus with proximal ulna in caudal view, main slab. Abbreviations: cb - crista bicipitalis, cd - crista deltopectoralis, ch - caput humeri, cv - condylus ventralis, fpd fossa pneumotricipitalis - dorsal part, fpv - fossa pneumotricipitalis - ventral part, ic - incisura capitis, ol - olecranon, pf - processus flexorius, slt - sulcus ligamentosus transversus, $\mathrm{td}$ - tuberculum dorsale, $\mathrm{tr}$ - transverse ridge, tv tuberculum ventrale. 

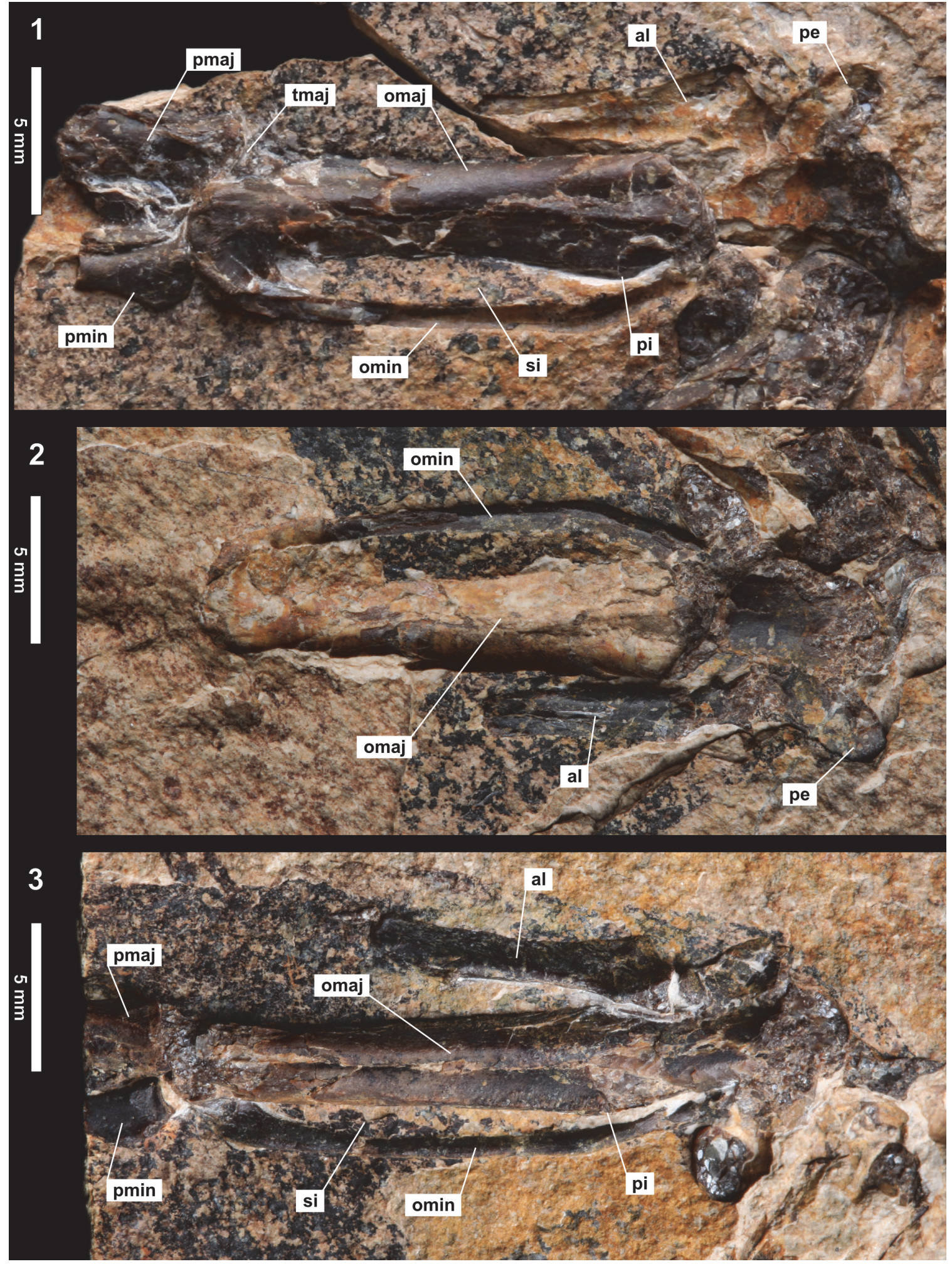

FIGURE 5. Sobniogallus albinojamrozi gen. et sp. nov., holotype, specimen ISEA AF/SOB1a+b from Sobniów, Poland, early Oligocene. 1, Right carpometacarpus in ventral view, counter slab; 2, imprint of right carpometacarpus, main slab; 3, left carpometacarpus in dorsal view, counter slab. Abbreviations: al - phalanx digiti alulae, omaj - os metacarpale majus, omin - os metacarpale minus, pe - processus extensorius, pi - rudimentary processus intermetacarpalis, pmaj - phalanx proximalis digiti majoris, pmin - phalanx digiti minoris, si - spatium intermetacarpale, tmaj - tuberosity of os metacarpale majus. 
TABLE 1. Measurements of Sobniogallus albinojamrozi gen. et sp. nov., holotype, specimen ISEA AF/SOB1a+b from Sobniów, Poland, early Oligocene compared with minimum and maximum values of all described specimens of chosen stem group Galliformes. Letters in superscript indicate publications that were checked for measurements.

Abbreviation: Pmaj - phalanx proximalis digiti majoris. a Alvarenga, 1995; b Dyke and Gulas, 2002; c Fischer, 1990; d Fischer, 2003; e Mayr, 2000; f Mayr, 2006; g Mayr and Smith, 2013; h Mayr and Weidig, 2004; i Mourer-Chauviré, 1992; k Mourer-Chauviré, 2000; I Mourer-Chauviré et al., 2013; m Tordoff and Macdonald, 1957

\begin{tabular}{|c|c|c|c|c|c|c|c|c|c|}
\hline & \multirow{2}{*}{$\begin{array}{c}\text { Coracoid } \\
\text { Length }\end{array}$} & \multicolumn{3}{|c|}{ Humerus } & \multirow{2}{*}{$\begin{array}{c}\text { Ulna } \\
\text { Length }\end{array}$} & \multicolumn{3}{|c|}{ Carpometacarpus } & \multirow{2}{*}{$\begin{array}{c}\text { Pmaj } \\
\text { Length }\end{array}$} \\
\hline & & Length & $\begin{array}{l}\text { Prox } \\
\text { width }\end{array}$ & $\begin{array}{l}\text { Dist } \\
\text { width }\end{array}$ & & Length & $\begin{array}{l}\text { Prox } \\
\text { width }\end{array}$ & $\begin{array}{c}\text { Dist } \\
\text { width }\end{array}$ & \\
\hline $\begin{array}{l}\text { Sobniogallus albinojamrozi } \\
\text { ISEA AF/SOB1a+b }\end{array}$ & 27.4 & 43.3 & 13.2 & 8.6 & 47.1 & 23.7 & 6.7 & 3.9 & 9.5 \\
\hline \multicolumn{10}{|l|}{ Gallinuloididae } \\
\hline Gallinuloides wyomingensis $\mathrm{hm}$ & 29.0 & 46.8-c.47.0 & - & - & c.48.4-49.2 & $25.5-c .27 .1$ & - & - & 10.7 \\
\hline Paraortygoides messelensis ef & - & c. $39.5-48.5$ & - & - & c. $40.0-47.2$ & $21.7-26.0$ & - & - & - \\
\hline Paraortygoides radagasti $\mathrm{b}$ & - & - & - & - & - & - & 7.5 & - & - \\
\hline \multicolumn{10}{|l|}{ Paraortygidae } \\
\hline Paraortyx lorteti gi & $22.1-27.0$ & $37.0-42.6$ & $9.2-11.2$ & $7.2-8.7$ & 36.8 & $19.5-21.7$ & $6.1-7.0$ & $3.9-4.2$ & - \\
\hline Paraortyx brancoi dgi & $31.0-35.3$ & $49.6-51.3$ & $12.2-12.9$ & $9.5-9.9$ & - & 27.0 & 7.7 & - & - \\
\hline Pirortyx major cdgi & $32.0-41.0$ & 56.4 & $12.8-14.4$ & $8.7-10.8$ & - & 30.6 & - & - & - \\
\hline \multicolumn{10}{|l|}{ Quercymegapodiidae } \\
\hline Quercymegapodius depereti ci & - & $39.7-40.4$ & $9.5-10.0$ & $7.0-7.7$ & - & 22.5 & 5.9 & 4.2 & - \\
\hline Quercymegapodius brodkorbi i & - & - & 8.2 & 5.7-c.5.8 & - & 19.4-19.8 & $5.1-5.6$ & 3.2 & - \\
\hline Ameripodius alexis $\mathrm{k}$ & $40.0-43.4$ & $73.2-87.7$ & $15.8-18.9$ & $12.6-14.8$ & 81.0 & $44.5-46.3$ & $5.8-6.0$ & $4.2-4.3$ & - \\
\hline Ameripodius silvasantosi ak & 28.0 & 45.8 & 11.5 & 8.4 & ?41-c.44 & $21.2-26.64$ & 7.0 & 4.9 & 11.6 \\
\hline Taubacrex granivora $\mathrm{k}$ & 31.5 & - & - & - & c. 48.0 & - & - & - & - \\
\hline \multicolumn{10}{|l|}{ Family? } \\
\hline Chambiortyx cristata I & - & - & - & - & - & - & - & 3.1 & - \\
\hline
\end{tabular}

in cross-section); in Gallinuloides and the most extant genera of Galliformes, the scapi claviculae are of equal width (i.e., circular in cross-section). The apophysis furculae is long and blade-like, which is a typical feature of extant Galliformes and, as noticed by Mayr (2000), present also in the middle Eocene Paraortygoides messelensis.

Coracoid. Both coracoids are visible in ventral view on the main slab: the right coracoid is well exposed whereas the left lies under the furcula and some matrix. On the counter slab, the right coracoid is a combination of fossilized bone (extremitas omalis) and impression of the ventral side (shaft and sternal end), and the left coracoid is represented by a small fragment of extremitas omalis. As in many stem group Galliformes including Quercymegapodius, Paraortyx, Paraortygoides, and Gallinuloides, the coracoid is relatively stout; in
Taubacrex it is less stout (shaft narrower). Similarly to extant Galliformes, it does not widen much towards its sternal end. The processus acrocoracoideus (Figure 3.2) is more rounded and straighter than in extant Galliformes, which agrees with the condition in stem group galliform birds. The cotyla scapularis and other details of the dorsal surface are not visible. The processus lateralis is small and only moderately extended but its exact shape is unclear. As in extant Galliformes, the angulus medialis is elongated and extends far medially into the foramen rostri of the sternum. In Ameripodius and Taubacrex, the angulus medialis is shorter whereas in Paraortyx it is more similar to Sobniogallus.

Humerus. Both humeri are visible in caudal view on the main slab: the right humerus is well exposed, whereas from the left humerus only por- 
tions are visible (proximal part and small fragments of the shaft and distal part) - the rest being hidden in the matrix and underneath the furcula and sternum. On the counter slab, the right humerus is mostly an imprint of the caudal surface and only the proximal part is preserved as bone in the cranial view. The left humerus is represented by a small imprint of the caput humeri. The humerus is relatively stout. Contrary to Anseriformes and more similar to extant Galliformes, the proximal end is small and rounded. As in extant Galliformes and the Palaeogene Quercymegapodius and Pirortyx, the fossa pneumotricipitalis is divided into two parts with deep ventral fossa and shallow second (i.e., dorsal) fossa in the form of a depression that does not extend into the caput humeri (Figure 4.1). In Paraortyx, Paraortygoides, and Gallinuloides, the second fossa pneumotricipitalis is well developed and extends into the caput humeri (Mayr, 2000; Mayr and Weidig, 2004; Mourer-Chauviré, 1992). Similarly to extant Anseriformes, the tuberculum ventrale is pronounced (Figure 4.1, 4.3, 4.5), whereas in Galliformes it is characteristically small (Bochenski and Tomek, 2009, p.29, character 3b). As in Ameripodius alexis and most specimens of Quercymegapodius, there is a weakly developed but clear transverse ridge at the beginning of the incisura capitis, which connects the caput humeri with the tuberculum ventrale (Figure 4.1, 4.3). A similar ridge, although higher and better developed, is also in all extant Galliformes, whereas in many early galliforms including Paraortyx, Pirortyx, Paraortygoides, and Gallinuloides the ridge is missing (Mayr, 2000; Mayr and Weidig, 2004; Mourer-Chauviré, 1992, 2000). Contrary to extant Galliformes, the tuberculum dorsale strongly projects and is separated from the caput humeri by a shallow furrow (Figure 4.1-2, 4.4). A projecting tuberculum dorsale was also noted in Ameripodius alexis, and a furrow between the tuberculum dorsale and the caput humeri was observed in Paraortygoides, although judging from the relevant illustrations (Mayr, 2000, text-figures 1, 4; MourerChauviré, 2000, plate 1) the tuberculum dorsale is much more distinct in Sobniogallus. In this respect, Quercymegapodius, Paraortyx, and Pirortyx seem to be more similar to extant Galliformes (MourerChauviré, 1992, figures 1, 2, 5). The sulcus ligamentosus transversus is much deeper than in any extant or Palaeogene galliform taxa and extends to the tuberculum ventrale (Figure 4.1, 4.3) - the character seems to be unique to Sobniogallus albinojamrozi. As in extant Anatidae and the early Eocene Paraortygoides, the crista bicipitalis meets the shaft of the humerus at a steeper angle than it does in other extinct or extant galliform birds (Figure 4.1, 4.5; Mayr, 2006). As in extant Galliformes but contrary to extant Anseriformes, the crista deltopectoralis is short proximo-distally and its distal end merges with the shaft approximately as far distally as the distal end of the crista bicipitalis (Figure 4.4). As in extant and extinct Galliformes, the ventral surface of the crista deltopectoralis is almost perpendicular to the cranial surface of the humerus shaft. Although a large part of the shaft is crushed, a small swelling is present on the caudal surface at the base of the proximal end, i.e., in the area that is flat in extant Galliformes (Figure 4.5). The swelling may represent the only preserved section of the longitudinal ridge, in the prolongation of the internal side of the fossa pneumotricipitalis (Mourer-Chauviré, 1992) - i.e., one of the diagnostic characters of the Quercymegapodiidae. As in many stem group Galliformes including Paraortyx, Quercymegapodius, and Paraortygoides, the processus flexorius reaches about as far distally as the condylus ventralis (Figure 4.6; Mayr, 2000; Mourer-Chauviré, 1992, figures 1,2), whereas in extant Galliformes it is always shorter than the condylus ventralis.

UIna. In its general shape, the ulna resembles that in extant Galliformes. The olecranon is short and blunt (Figure 4.6), and the shaft shows poorly marked papillae remigiales (three of them are visible on the right ulna). Like in most extant Megapodiidae, some Cracidae and the early Eocene Gallinuloides wyomingensis, but contrary to most extant Phasianidae, Ludiortyx hoffmanni, Paraortyx lorteti, and Paraortygoides messelensis, the ulna is a little longer than the humerus. No meaningful details on the distal end are visible.

Radius. The radius remains in articulation and is too poorly preserved to allow meaningful comparison.

Carpometacarpus. The carpometacarpi are preserved as a combination of bone fragments and impressions on both slabs, and therefore both dorsal and ventral surfaces are visible, although not all details are recognizable. The general morphology of the carpometacarpus is very different from that observed in extant Galliformes and resembles more Anseriformes: the bone is slender because the os metacarpale minus is straight and roughly parallel to the os metacarpale majus and, as a consequence, the spatium intermetacarpale is narrow (Figure 5). Such an "anseriform" carpometacarpus is a primitive condition in galliform birds and is observed on various Palaeogene specimens of 
Paraortyx lorteti, cf. Pirortyx major, Quercymegapodius depereti, Q. brodkorbi, Paraortygoides messelensis, and Gallinuloides wyomingensis, as well as late Oligocene and/or early Miocene Ameripodius silvasantosi and $A$. alexis whose carpometacarpi are narrow and elongated (Alvarenga, 1995; Mayr, 2000; Mayr and Smith, 2013; Mayr and Weidig, 2004; Mourer-Chauviré, 1992, 2000; Weidig, 2010). As in extant Galliformes but contrary to Anseriformes, the os metacarpale majus curves distinctly dorso-ventrally: its both ends extend farther ventrally than its mid-section. The character is visible at the right and the left carpometacarpus and therefore it is unlikely to be of diagenetic origin. The processus extensorius (Figure 5.1-2) is more protruding proximo-cranially than in extant Galliformes and extinct Paraortyx and Quercymegapodius; in this respect it resembles Paraortygoides and Gallinuloides. As in many early galliforms (Quercymegapodius, Ameripodius alexis, Paraortyx lorteti, cf. Pirortyx major), the processus intermetacarpalis is rudimentary and represented only by a small bulge or ridge that does not reach the os metacarpale minus (Figure 5.1, 5.3). In some other early galliform species (Paraortygoides, Ameripodius silvasantosi), it is completely missing. All extant Galliformes except Numida bear the processus (Tomek and Bochenski, 2009) but in Cracidae and Megapodiidae it is rudimentary. The "hook-like, distally incurved apophysis on the internal [i.e., ventral] face of the os metacarpale minus" listed by Mourer-Chauviré (1992) in the original description as one of the diagnostic characters of the Quercymegapodiidae, is either absent or not visible because the only preserved fragment of the os metacarpale minus is seen in the dorsal view, with the ventral side in the matrix. As in many extant Anseriformes, the articular surface of the os metacarpale minus extends slightly less distally than the articular surface of the os metacarpale majus (Figure 5.1-3). In all extant Galliformes except the Megapodiidae, the articular surface of the os metacarpale minus extends much farther distally. In Quercymegapodiidae, a little variation is observed: in Quercymegapodius brodkorbi, the two ossa metacarpalia protrude about the same far distally (Mourer-Chauviré, 1992, figure 1), whereas in Q. depereti and Ameripodius alexis, the articular surface of the os metacarpale minus extends slightly more distally than the surface of the major digit (Mourer-Chauviré, 1992, figure 1; MourerChauviré, 2000, plate 1; respectively). In Paraortyx, Paraortygoides and Gallinuloides, the two ossa metacarpalia protrude about the same far distally (Fisher, 2003, figure 13; Mayr, 2000, figure 5; Mayr, 2006, figure 4; Mayr and Weidig, 2004, figure 5; Mourer-Chauviré, 1992, figure 2). As in extant Galliformes but contrary to extant Anseriformes, a tuberosity on the anterior side of the os metacarpale majus is situated more proximad than the articular surface of the os metacarpale majus (Figure 5.1).

Other elements of the wing. The short and wide phalanx proximalis digiti majoris resembles the corresponding bone in Galliformes. As in Gallinuloides, it is only slightly shorter than the phalanx distalis digiti majoris; in Paraortygoides, the two phalanges are of about equal length, whereas in Ameripodius silvasantosi the phalanx distalis is slightly shorter than the proximalis. The phalanx digiti alulae is very long: almost as long as half the length of the carpometacarpus, whereas in Paraortygoides and Gallinuloides it was relatively shorter (Mayr, 2000, figure 1; Mayr, 2006, figure 1; Mayr and Weidig, 2004, figure 2; Weidig, 2010, figure 1). As in many extant Galliformes and the Eocene Paraortygoides and Gallinuloides, there is a small claw on the phalanx digiti alulae (Mayr, 2006; Stephan, 1992; Weidig, 2010). The wing phalanges of Paraortyx, Pirortyx, and Quercymegapodius are unknown.

Tibiotarsus. A poorly preserved proximal part of the right tibiotarsus is visible on both slabs. As in most extant Galliformes, the distal margin of the crista cnemialis lateralis is nearly perpendicular to the long axis of the bone. Other structures are too poorly preserved to allow meaningful comparison.

Feathers. Structural elements of the flight feathers (barbs) can be discerned in multiple places within the dark area around the right wing. Although the outline of particular feathers remains obscure, it is possible to estimate the approximate length of the folded wing at ca. $130 \mathrm{~mm}$ which is somewhat shorter than that of the extant Grey Partridge Perdix perdix (151-166 mm) (Cramp and Simmons, 1980). The longest primaries, as inferred from the size of the dark area near the carpometacarpus and wing phalanges, are about $110 \mathrm{~mm}$ long, the secondaries (dark area near the ulna) measure about $80 \mathrm{~mm}$, and the longest tertial (dark area near the humerus) is about $80-90 \mathrm{~mm}$.

\section{DISCUSSION}

There is no doubt that Sobniogallus albinojamrozi belongs to Galliformes, as no other group of birds shows such a combination of highly specific characters, mainly of the sternum, furcula, and humerus (see above). However, a more detailed 
position of the specimen within Galliformes is unclear, as some vital characters distinguishing particular phylogenetic nodes of this group (Mayr, 2000, text-figure 10; Mayr and Weidig, 2004, figure 7) are not preserved (e.g., cotyla scapularis of the coracoid). The primitive morphology of the "anseriform" carpometacarpus precludes the inclusion of Sobniogallus albinojamrozi into the crown group Galliformes and indicates its position somewhere within the stem groups (Mayr and Weidig, 2004). The presence of a transverse ridge that connects the caput humeri with the tuberculum ventrale (humerus) eliminates Gallinuloididae and Paraortygidae, and at the same time, this character along with a rudimentary processus intermetacarpalis (carpometacarpus) point to Quercymegapodiidae. However, other quercymegapodiid characters listed in the original diagnosis (Mourer-Chauviré, 1992) are not visible on Sobniogallus, possibly due to the missing tarsometatarsus, damaged humerus, and unfavorable position of the coracoid and carpometacarpus. Additionally, as shown above, Sobniogallus differs in some osteological details from all genera of Quercymegapodiidae (Quercymegapodius, Ameripodius, and Ludiortyx), and therefore we prefer to describe it as incertae sedis until better preserved specimens are discovered.

Sobniogallus is the oldest representative of Galliformes with the rostrum sterni resembling that in extant birds. The spina communis and the foramen rostri are highly characteristic of modern Galliformes, yet as shown in this paper their origin can be traced back to a stem group species that otherwise shows many primitive conditions. Palaeogene Galliformes are known to show a mixture of derived and primitive conditions, the latter sometimes resembling those of extant Anseriformes and hence being described as "anseriform" characters (e.g., Mayr and Weidig, 2004). That is in agreement with the growing consensus, from both molecular and morphological studies (e.g., Cracraft et al., 2004; Dzerzhinsky, 1995; Hackett et al., 2008; Livezey and Zusi, 2006, 2007; Mayr and Clarke, 2003; McCormack et al., 2013), that Galliformes and Anseriformes are sister taxa that together form the clade Galloanseres. The present study supports the theory by providing another example of morphological similarities.

The lack of the head with a bill, legs, and clear feather imprints of Sobniogallus albinojamrozi prevents us from drawing any reliable conclusions on the bird's mode of life and feeding habits.
The present specimen of an extinct galliform bird increases the already known high diversity of the Palaeogene avian remains recovered from the Outer Carpathians and Central Paleogene Basin. Although such findings are very rare (Bochenski et al., 2012), they represent taxonomically very diversified groups. So far, remains that belong to five different avian orders (Procellariiformes, Apodiformes, Coraciiformes, Piciformes, and Passeriformes) were reported, some of them representing new species or even genera (Bochenski and Bochenski, 2008; Bochenski et al., 2011, 2013b, 2014a, 2014b; Elzanowski et al., 2012; Gregorová, 2006; Kundrát et al., in press; Mayr and Gregorová, 2012). This is an obvious indication of the complex habitats in that part of the Paratethys, which must have been similar in this respect to other parts of Europe that were inhabited by very diversified avifauna during the Palaeogene (Mayr, 2009).

\section{ACKNOWLEDGMENTS}

We thank M. Bujoczek (Faculty of Forestry, University of Agriculture, Kraków, Poland) for her comments on feather remains that are visible on the specimens, and G. Mayr (Senckenberg Research Institute and Natural History Museum, Frankfurt am Main, Germany) for his suggestions on how to improve the earlier version of the manuscript.

\section{REFERENCES}

Alvarenga, H.M.F. 1988. Ave fóssil (Gruiformes: Rallidae) dos folhelhos da Bacia de Taubaté, estado de São Paulo, Brasil. Anais da Academia Brasileira de Ciências, 60:321-332.

Alvarenga, H.M.F. 1995. Um primitivo membro da Ordem Galliformes (Aves) do Terciário Médio da Bacia de Taubaté, estado de São Paulo, Brasil. Anais da Academia Brasileira de Ciências, 67:33-44.

Baumel, J.J. and Witmer, L.M. 1993. Osteologia, p. 45132. In Baumel, J.J., King, A.S., Breazile, J.E., Evans, H.E., and Vanden Berge, J.C. (eds.), Handbook of Avian Anatomy: Nomina Anatomica Avium. Nuttall Ornithological Club, Cambridge, Massachusetts.

Berggren, W.A., Kent, D.V., Swisher, C.C., and Aubry, M.P. 1995. A revised Cenozoic geochronology and chronostratigraphy, p. 129-212. In Berggren, W.A., Kent, D.V., Aubry, M.P., and Hardenbol, J. (eds.), Geochronology, Time Scales and Global Stratigraphic Correlation. SEPM Special Publication No.54. Society for Sedimentary Geology, Tulsa. 
Bochenski, Z. and Bochenski, Z.M. 2008. An Old World hummingbird from the Oligocene: a new fossil from Polish Carpathians. Journal of Ornithology, 149:211216.

Bochenski, Z.M. and Tomek, T. 2009. A Key for the Identification of Domestic Birds Bones in Europe: Preliminary Determination. Institute of Systematics and Evolution of Animals of the Polish Academy of Sciences, Kraków.

Bochenski, Z., Bochenski, Z.M., and Tomek, T. 2012. A History of Polish Birds. Publications of the Institute of Systematics and Evolution of Animals, Kraków.

Bochenski, Z.M., Tomek, T., and Swidnicka, E. 2013a. A review of avian remains from the Oligocene of the Outer Carpathians and Central Paleogene basin, $p$. 37-41. In Göhlich, U.B. and Kroh, A. (eds.), Paleornithological research 2013 - Proceedings of the 8th International Meeting of the Society of Avian Paleontology and Evolution. Naturhistorisches Museum Wien, Vienna.

Bochenski, Z.M., Tomek, T., and Swidnicka, E. 2014a. A complete passerine foot from the late Oligocene of Poland. Palaeontologica Electronica 17.1.6A:7pp.

Bochenski, Z.M., Tomek, T., and Swidnicka, E. 2014b. The first complete leg of a passerine bird from the early Oligocene of Poland. Acta Palaeontologica Polonica, 59:281-285.

Bochenski, Z.M., Tomek, T., Bujoczek, M., and Wertz, K. 2011. A new passerine bird from the early Oligocene of Poland. Journal of Ornithology, 152:1045-1053.

Bochenski, Z.M., Tomek, T., Wertz, K., and Swidnicka, E. 2013b. The third nearly complete passerine bird from the early Oligocene of Europe. Journal of Ornithology, 154:923-931. (Open Access).

Brodkorb, P. 1964. Catalogue of fossil birds: Part 2 (Anseriformes through Galliformes). Bulletin of the Florida State Museum, Biological Sciences, 8:195335.

Cracraft, J., Barker, F.K., Braun, M., Harshman, J., Dyke, G.J., Feinstein, J., Stanley, S., Cibois, A., Schikler, P., Beresford, P., García-Moreno, J., Sorenson, M.D., Yuri, T., and Mindell, D.P. 2004. Phylogenetic relationships among modern birds (Neornithes): toward an avian tree of life, p. 468-489. In Cracraft, J. and Donoghue, M. (eds.), Assembling the Tree of Life. Oxford University Press, New York.

Cramp, S. and Simmons, K.E.L. (eds.) 1980. Handbook of the Birds of Europe, the Middle East and North Africa. The Birds of the Western Palearctic, Volume II:Hawks to Bustards. Oxford University Press, Oxford.

Crowe, T.M. and Short, L.L. 1992. A new Gallinaceous bird from the Oligocene of Nebraska, with comments on the phylogenetic position of the Gallinuloididae, $p$. 179-185. In Campell, K.E. (ed.), Papers in Avian Paleontology Honoring Pierce Brodkorb. Science Series, No. 36. Natural History Museum of Los Angeles County, Los Angeles. del Hoyo, J., Elliott, A., and Sargatal, J. (eds.) 1994. Handbook of the Birds of the World, Volume 2: New World Vultures to Guineafowl. Lynx Edicions, Barcelona.

Dyke, G.J. and Gulas, B.E. 2002. The fossil galliform bird Paraortygoides from the Lower Eocene of the United Kingdom. American Museum Novitates, 3360:1-14.

Dzerzhinsky, F.Y. 1995. Evidence for common ancestry of the Galliformes and Anseriformes. Courier Forschungsinstitut Senckenberg, 181:325-336.

Eastman, C.R. 1900. New fossil bird and fish remains from the Middle Eocene of Wyoming. Geological Magazine (new series), decade 4, 7:54-58.

Elzanowski, A., Bienkowska-Wasiluk, M., Chodyn, R., and Bogdanowicz, W. 2012. Anatomy of the coracoid and diversity of the Procellariiformes (Aves) in the Oligocene of Europe. Palaeontology, 55:1199-1221.

Fischer, K. 1990. Der Hühnervogel Pirortyx major (Gaillard, 1939) aus dem marinen Mitteloligozän bei Leipzig (DDR). Mitteilungen aus dem Zoologischen Museum Berlin, 66 (Supplement: Annalen für Ornithologie, 14):133-136.

Fischer, K. 2003. Weitere Vogelknochen von Diomedeoides (Diomedeoididae, Procellariiformes), und Paraortyx (Paraortygidae, Galliformes) aus dem Unteroligozän des Weißelsterbeckens bei Leipzig. Mauritiana, 18:387-395.

Gaillard, C. 1908. Les oiseaux des phosphorites du Quercy. Annales de l'Université de Lyon (nouvelle série), 23:1-178.

Gervais, P. 1848-1852. Zoologie et Paléontologie Françaises (Animaux Vertébrés), ou Nouvelles Recherches sur les Animaux Vivants et Fossiles de la France, tomes 1-3. Arthus Bertrand, Paris.

Gregorová, R. 2006. A new discovery of a seabird (Aves: Procellariiformes) in the Oligocene of the "Menilitic Formation" in Moravia (Czech Republic). Hantkeniana, 5:90.

Hackett, S.J., Kimball, R.T., Reddy, S., Bowie, R.C.K., Braun, E.L., Braun, M.J., Chojnowski, J.L., Cox, W.A., Han, K., Harshman, J., Huddleston, C.J., Marks, B.D., Miglia, K.J., Moore, W.S., Sheldon, F.H., Steadman, D.W., Witt, C.C., and Yuri, T. 2008. A phylogenomic study of birds reveals their evolutionary history. Science, 320:1763-1768.

Haczewski, G. 1989. Coccolith limestone horizons in the Menilite-Krosno series (Oligocene, Carpathians) identification, correlation and origin. Annales Societatis Geologorum Poloniae, 59:435-529. (In Polish with English summary)

Harrison, C.J.O. and Walker, C.A. 1977. Birds of the British Lower Eocene. Tertiary Research Special Paper, $3: 1-52$

Jerzmańska, A. 1960. Ichthyofauna from the Jasło shales at Sobniów (Poland). Acta Palaeontologica Polonica, 5:367-419. (In Polish with English summary) 
Jerzmańska, A. and Jucha, S. 1963. L'affleurement de la faune de poissons dans les schistes de Jasło à Łubno près de Dynów (Carpates Polonaises). Rocznik Polskiego Towarzystwa Geologicznego, 33:159-180. (In Polish with French summary)

Jucha, S. 1969. Les schistes de Jasło, leur importance pour la stratigraphie et la sédimentologie de la série ménilitique et des couches de Krosno (Carpates flyscheuses). Prace Geologiczne, 52:7-128. (In Polish with French summary)

Kotlarczyk, J., Jerzmańska, A., Swidnicka, E., and Wiszniowska, T. 2006. A framework of ichthyofaunal ecostratigraphy of the Oligocene - early Miocene strata of the Polish Outer Carpathian basin. Annales Societatis Geologorum Poloniae, 76:1-111.

Ksepka, D.T. 2009. Broken gears in the avian molecular clock: new phylogenetic analyses support stem galliform status for Gallinuloides wyomingensis and rallid affinities for Amitabha urbsinterdictensis. Cladistics, 25:173-197.

Kundrát, M., Soták, J., and Ahlberg, P.E. in press. A putative upupiform bird from the Early Oligocene of the Central Western Carpathians and a review of fossil birds unearthed in Slovakia. Acta Zoologica. doi: 10.1111/azo. 12050

Linnaeus, C. 1758. Systema naturae per regna tria naturae: secundum classes, ordines, genera, species, cum characteribus, differentiis, synonymis, locis (10th edition). Laurentius Salvius, Stockholm.

Livezey, B.C. and Zusi, R.L. 2006. Higher-order phylogeny of modern birds (Theropoda, Aves: Neornithes) based on comparative anatomy: I. Methods and characters. Bulletin of the Carnegie Museum of Natural History, 37:1-544.

Livezey, B.C. and Zusi, R.L. 2007. Higher-order phylogeny of modern birds (Theropoda, Aves: Neornithes) based on comparative anatomy: II. Analysis and discussion. Zoological Journal of the Linnean Society, 149:1-95.

Martini, E. 1971. Standard Tertiary and Quaternary calcareous nannoplankton zonation, p. 739-785. In Farrinacci, A. (ed.), Proceedings of the II Planktonic Conference, Roma, 1970: Volume 2. Edizioni Tectoscienza, Rome.

Mayr, G. 2000. A new basal galliform bird from the Middle Eocene of Messel (Hessen, Germany). Senckenbergiana Lethaea, 80:45-57.

Mayr, G. 2005. The Paleogene fossil record of birds in Europe. Biological Reviews, 80:515-542.

Mayr, G. 2006. New specimens of the early Eocene stem group galliform Paraortygoides (Gallinuloididae), with comments on the evolution of a crop in the stem lineage of Galliformes. Journal of Ornithology, 147:3137.

Mayr, G. 2009. Paleogene Fossil Birds. Springer, Berlin.

Mayr, G. and Clarke, J. 2003. The deep divergences of neornithine birds: a phylogenetic analysis of morphological characters. Cladistics, 19:527-553.
Mayr, G. and Gregorová, R. 2012. A tiny stem group representative of Pici (Aves: Piciformes) from the early Oligocene of the Czech Republic. Paläontologische Zeitschrift, 86:333-343.

Mayr, G. and Smith, T. 2013. Galliformes, Upupiformes, Trogoniformes, and other avian remains (?Phaethontiformes and ?Threskiornithidae) from the Rupelian stratotype in Belgium, with comments on the identity of "Anas" benedeni Sharpe, 1899, p. 23-35. In Göhlich, U.B. and Kroh, A. (eds.), Paleornithological Research 2013 - Proceedings of the 8th International Meeting of the Society of Avian Paleontology and Evolution. Natural History Museum Vienna, Vienna.

Mayr, G. and Weidig, I. 2004. The early Eocene Gallinuloides wyomingensis (Aves: Gallinuloididae) is a stem group representative of Galliformes. Acta Palaeontologica Polonica, 49:211-217.

McCormack, J.E., Harvey, M.G., Faircloth, B.C., Crawford, N.G., Glenn, T.C., and Brumfield. R.T. 2013. A phylogeny of birds based on over 1,500 loci collected by target enrichment and high-throughput sequencing. Plos One, 8:e54848.

Milne-Edwards, A. 1867-1871. Recherches Anatomiques et Paléontologiques pour Servir à l'Histoire des Oiseaux Fossiles de la France, tomes 1-2. Victor Masson et fils, Paris.

Mourer-Chauviré, C. 1992. The Galliformes (Aves) from the Phosphorites du Quercy (France): systematics and biostratigraphy, p. 67-95. In Campell, K.E. (ed.), Papers in Avian Paleontology Honoring Pierce Brodkorb. Science Series, No. 36. Natural History Museum of Los Angeles, Los Angeles.

Mourer-Chauviré, C. 2000. A new species of Ameripodius (Aves: Galliformes: Quercymegapodiidae) from the lower Miocene of France. Palaeontology, 43:481493.

Mourer-Chauviré, C., Pickford, M., and Senut, B. 2011. The first Palaeogene galliform from Africa. Journal of Ornithology, 152:617-622.

Mourer-Chauviré, C., Tabuce, R., El Mabrouk, E., Marivaux, L., Khayati, H., Vianey-Liaud, M., and Ben Haj Ali, M. 2013. A new taxon of stem group Galliformes and the earliest record for stem group Cuculidae from the Eocene of Djebel Chambi, Tunisia, p. 115. In Göhlich, U.B. and Kroh, A. (eds.), Paleornithological Research 2013 - Proceedings of the 8th International Meeting of the Society of Avian Paleontology and Evolution. Natural History Museum Vienna, Vienna.

Stephan, B. 1992. Vorkommen und Ausbildung der Fingerkrallen bei rezenten Vögeln. Journal of Ornithology, 133:251-277.

Temminck, C.J. 1820. Manuel d'ornithologie, ou Tableau systématique des oiseaux qui se trouvent en Europe; précédé d'une analyse $d u$ système général d'ornithologie, et suivi d'une table alphabeétique des espèces (2th edition). Gabriel Dufour, Paris. 
Tomek, T. and Bochenski, Z.M. 2009. A Key for the Identification of Domestic Bird Bones in Europe: Galliformes and Columbiformes. Institute of Systematics and Evolution of Animals of the Polish Academy of Sciences, Kraków.
Tordoff, H.B. and Macdonald, J.R. 1957. A new bird (family Cracidae) from the early Oligocene of South Dakota. Auk, 74:174-184.

Weidig, I. 2010. New birds from the Lower Eocene Green River Formation, North America. Records of the Australian Museum, 62:29-44. 